\title{
The dynamic provision of different energy substrates improves development of one-cell random-bred mouse embryos in vitro
}

\author{
J. J. G. Brown*† and D. G. Whittingham \\ Medical Research Council, Experimental Embryology and Teratology Unit, St George's Hospital \\ Medical School, London SWI7 ORE, UK
}

\begin{abstract}
Summary. Preliminary observations showed that one-cell embryos from random-bred MFl mice avoid cleavage arrest at the two-cell stage ('in vitro two-cell block') when cultured in modified M16 culture medium containing lactate and pyruvate but lacking glucose. The roles of lactate, pyruvate and glucose during preimplantation development of embryos from random-bred mice in vitro were therefore examined. When all three substrates were present continuously during culture, one-cell embryos arrested at the two- to four-cell stages. Improved development to the morula stage after $96 \mathrm{~h}$ in culture was obtained in media containing pyruvate alone, lactate and pyruvate, pyruvate and glucose, lactate pyruvate and glucose for the first $24 \mathrm{~h}$, and medium containing lactate and pyruvate for the remaining $72 \mathrm{~h}$. In a second experiment, embryos were cultured in medium containing pyruvate alone, lactate and pyruvate or pyruvate and glucose for the first $24 \mathrm{~h}$, and lactate plus pyruvate medium for the second $24 \mathrm{~h}$. Subsequent transfer to medium containing lactate, pyruvate and glucose supported the morula to blastocyst transition. These results show that developmental arrest in vitro can be overcome by changing the combination of energy substrates at different stages of preimplantation development.
\end{abstract}

Keywords: preimplantation; embryo; blastocyst; two-cell block; culture; mouse

\section{Introduction}

Mouse embryos of all strains can develop into blastocysts when cultured from the late two-cell stage in simple chemically defined physiological salt solutions containing the energy substrates lactate, pyruvate and glucose (Brinster, 1965a, b; Biggers et al., 1967, 1971). However, the embryos of most strains arrest at the two- to four-cell stage when cultured from the one-cell stage, a phenomenon commonly referred to as the 'in-vitro two-cell block'. Only the embryos of certain inbred strains, and their $F_{1}$ hybrids, develop consistently from the one-cell to blastocyst stage under these conditions (Whitten \& Biggers, 1968; Biggers, 1971; 1987). Previously, it has been shown that the block may be obviated when arrested embryos are transferred to explanted oviducts in organ culture (Whittingham \& Biggers, 1967) or when the cytoplasm from embryos of a nonblocking strain is injected into arrested two-cell stage embryos (Muggleton-Harris et al., 1982; Muggleton-Harris \& Brown, 1988).

$\mathrm{F}_{2}$ hybrid embryos of inbred origin, which do not arrest at the two-cell stage in vitro, require glucose for the transition from morula to blastocyst in vitro (Brown \& Whittingham, 1990b, 1991). Preliminary studies indicated that most one-cell embryos from random-bred MF1 mice avoid

*Present address: Department of Pathology, Tufts University, 136 Harrison Avenue, Boston MA 02111, USA.

+Correspondence and reprint requests. 
cleavage arrest at the two-cell stage, and develop into morulae, when cultured in modified M16 mouse embryo culture medium (Whittingham, 1971) containing lactate and pyruvate but lacking glucose (Brown \& Whittingham, 1990a). This observation is consistent with the findings of Chatot et al. (1989), who developed an improved medium for the culture of one-cell random-bred mouse embryos. The formulation of the medium (CZB) is based on the observation that glucose inhibits development of cultured two-cell (Schini \& Bavister, 1988) and eight-cell (Seshagiri \& Bavister, 1989a) hamster embryos, and glutamine improves the development of cultured eight-cell hamster embryos (Carney \& Bavister, 1987). It is a modification of BMOC-2 (Ebert \& Brinster, 1983) with an increased lactate:pyruvate ratio of 116 (Cross \& Brinster, 1973), 0.1 mmol EDTA $1^{-1}$ (Abramczuk et al., 1977), $1 \mathrm{mmol}$ glutamine $1^{-1}$ (Carney \& Bavister, 1987) and no glucose. This medium improves development from the one-cell to morula stage, but the addition of glucose after the first $48 \mathrm{~h}$ of culture is necessary for consistent development to the blastocyst stage (Chatot et al., 1989, 1990a, b).

The interactions between substrates are important in meeting the energetic requirements of cultured mouse embryos (Brinster, 1965b). Improved development of one-cell embryos from random-bred mice has been achieved by changing the combination and concentration of energy substrates at various times during culture (Cross \& Brinster, 1973). This study examines the specific roles of lactate, pyruvate and glucose (and their interactions), and the possible role of glutamine, at various times during culture of one-cell mouse embryos of random-bred origin.

\section{Materials and Methods}

\section{Embryo collection and culture}

Fertilized one-cell embryos were obtained from random-bred albino MF1/Lac females mated to MFI/Lac males. The mice were superovulated with intraperitoneal injections of 5 iu pregnant mares' serum gonadotrophin (PMSG; Folligon: Intervet, UK) followed $48 \mathrm{~h}$ later by 5 iu human chorionic gonadotrophin (hCG; Chorulon: Intervet, UK). In all experiments, fertilized one-cell embryos were recovered from the oviductal ampullae of mated females between 26 and $27 \mathrm{~h}$ after hCG injection. The cumulus cells were dispersed with hyaluronidase $\left(150 \mathrm{iu} \mathrm{ml} \mathrm{m}^{-1}\right)$ in Hepes-buffered mouse embryo handling medium, M2 (Fulton \& Whittingham, 1978; Quinn et al., 1982), and the embryos washed twice in M2 $(2 \times 2 \mathrm{ml})$. Embryos were cultured in bicarbonate-buffered mouse embryo culture medium, M16 (Whittingham, 1971) or modified Ml6 in which one or more of the energy substrates (lactate; pyruvate; glucose) was omitted. Media are referred to in the text according to the energy substrates they contain. Culture medium was freshly prepared each week from isotonic stock solutions of the various components so that changes in osmolarity, caused by the omission of energy substrate(s), could be adjusted simply by the addition of extra $\mathrm{NaCl}$ stock. The concentrations of lactate, pyruvate and glucose in all media were the same as those in unmodified M16 (23.28 mmol sodium lactate $\mathrm{I}^{-1}, 0.33 \mathrm{mmol}$ sodium pyruvate $\mathrm{l}^{-1}$ (Sigma, UK), $5.56 \mathrm{mmol}$ glucose $\mathrm{l}^{-1}(\mathrm{BDH}, \mathrm{UK})$ ). After washing thoroughly through $2 \times 2 \mathrm{ml}$ changes of the medium in which they were to be cultured, embryos were placed in small drops $(10 \mu \mathrm{l})$ of the same medium (10 embryos per drop) under light paraffin oil (BDH, UK) in $60 \mathrm{~mm}$ plastic tissue culture dishes (Falcon, UK). Medium and oil were previously equilibrated with $5 \% \mathrm{CO}_{2}$ in air at $37^{\circ} \mathrm{C}$. Embryos were cultured in a humidified atmosphere of $5 \% \mathrm{CO}_{2}$ in air at $37^{\circ} \mathrm{C}$ as described previously (Biggers et al., 1971), and developmental progress scored daily. Embryos in all treatments were taken through the washing procedures irrespective of whether they were to be transferred to the same, or different, media for the next culture period.

\section{Experimental design and statistical analysis}

Each experiment was repeated three times on three consecutive days, except for Expt I which was repeated three times in three separate weeks. Owing to the large number of treatments (36) involved in Expt 1, and thus the considerable amount of washing involved in the transfer of embryos to different media each day, this was divided into three component experiments (12 treatments in each) carried out on different days. We ensured that experimental bias was not introduced by the use of embryos collected from different batches of mice on different days by randomly allocating the treatments in each replicate to the three component experiments using a table of random numbers between 1 and 100 (Fisher \& Yates, 1963). A randomized incomplete block design was used, which omitted the glucose-only medium, since preliminary studies showed this could not support first or second cleavage in random-bred MF1 embryos in vitro (J. Brown, unpublished observations).

All embryos collected on each day were pooled in the final M2 wash before being allocated to the different treatments. Since no marked differences in development were observed within treatments between replicates, the data 
Table 1. The effects of lactate, pyruvate and glucose on development of one-cell MF1 embryos in vitro

\begin{tabular}{|c|c|c|c|c|c|c|c|c|}
\hline \multirow[b]{2}{*}{$\begin{array}{l}\text { Treatment } \\
\text { number }\end{array}$} & \multicolumn{2}{|c|}{ Medium $^{\mathbf{a}}$} & \multirow[b]{2}{*}{$\begin{array}{l}\text { Number of } \\
\text { embryos }^{b}\end{array}$} & \multirow{2}{*}{$\begin{array}{l}\% \text { two-cell } \\
\text { after } 24 \mathrm{~h} \\
\text { in culture }\end{array}$} & \multicolumn{4}{|c|}{$\begin{array}{l}\text { Percentage of embryos developing } \\
\text { to the various preimplantation } \\
\text { stages during } 96 \mathrm{~h} \text { in culture }\end{array}$} \\
\hline & $\begin{array}{c}\text { Day } \\
1\end{array}$ & $\begin{array}{l}\text { Days } \\
2-5\end{array}$ & & & Two-cell & $\begin{array}{l}\text { Four-to } \\
\text { eight-cell }\end{array}$ & Morula & Blastocyst \\
\hline I & $\mathrm{L}$ & L & 70 & & 69 & 16 & 0 & 0 \\
\hline 2 & $\mathrm{~L}$ & $\mathbf{P}$ & 70 & & 59 & 3 & 0 & 0 \\
\hline 3 & $\mathrm{~L}$ & LP & 70 & 53 & 61 & 20 & 0 & 0 \\
\hline 4 & $\mathrm{~L}$ & LG & 70 & & 64 & 11 & 0 & 0 \\
\hline 5 & L & PG & 70 & & 76 & 11 & 0 & 0 \\
\hline 6 & $\mathrm{~L}$ & LPG & 60 & & 67 & 17 & 0 & 0 \\
\hline 7 & $\mathbf{P}$ & $\mathrm{L}$ & 60 & & 93 & 27 & 0 & 0 \\
\hline 8 & $P$ & P & 60 & & 93 & 37 & 0 & 0 \\
\hline 9 & $P$ & LP & 70 & 81 & 83 & 69 & 41 & 0 \\
\hline 10 & $\mathbf{P}$ & LG & 70 & & 80 & 9 & 0 & 0 \\
\hline 11 & $\mathbf{P}$ & PG & 70 & & 90 & 11 & 0 & 0 \\
\hline 12 & $\mathbf{P}$ & LPG & 70 & & 90 & 59 & 10 & 6 \\
\hline 13 & LP & L & 70 & & 93 & 34 & 1 & 0 \\
\hline 14 & LP & P & 70 & & 94 & 47 & 1 & 0 \\
\hline 15 & LP & LP & 60 & 89 & 90 & 75 & 33 & 0 \\
\hline 16 & LP & LG & 80 & & 92 & 32 & 1 & 1 \\
\hline 17 & LP & PG & 80 & & 79 & 20 & 3 & 3 \\
\hline 18 & LP & LPG & 60 & & 97 & 73 & 22 & 13 \\
\hline 19 & LG & L & 60 & & 45 & 7 & 0 & 0 \\
\hline 20 & LG & P & 60 & & 60 & 10 & 0 & 0 \\
\hline 21 & LG & LP & 70 & 55 & 70 & 21 & 4 & 0 \\
\hline 22 & LG & LG & 60 & & 68 & 17 & 0 & 0 \\
\hline 23 & LG & PG & 70 & & 77 & 7 & 0 & 0 \\
\hline 24 & LG & LPG & 50 & & 86 & 34 & 0 & 0 \\
\hline 25 & PG & L & 80 & & 95 & 32 & 10 & 3 \\
\hline 26 & PG & $P$ & 50 & & 94 & 60 & 0 & 0 \\
\hline 27 & PG & LP & 70 & 88 & 93 & 83 & 59 & 9 \\
\hline 28 & PG & LG & 80 & & 89 & 30 & 0 & 0 \\
\hline 29 & PG & PG & 70 & & 93 & 24 & 0 & 0 \\
\hline 30 & PG & LPG & 70 & & 94 & 77 & 24 & 9 \\
\hline 31 & LPG & $\mathrm{L}$ & 60 & & 93 & 23 & 2 & 0 \\
\hline 32 & LPG & P & 60 & & 87 & 32 & 0 & 0 \\
\hline 33 & LPG & LP & 70 & 92 & 97 & 81 & 44 & 0 \\
\hline 34 & LPG & LG & 50 & & 92 & 38 & 4 & 0 \\
\hline 35 & LPG & PG & 60 & & 95 & 38 & 0 & 0 \\
\hline 36 & LPG & LPG & 70 & & 94 & 76 & 17 & 3 \\
\hline
\end{tabular}

${ }^{2}$ Embryos transferred to medium on day 1, 26-27 h after hCG; day 2, 46-48 h after hCG.

${ }^{6}$ Results pooled from three replicate experiments.

L: Lactate; P: pyruvate; G: glucose.

from each were pooled. Differences between treatments were tested by $\chi^{2}$ analysis of the combined data, using Yates' correction for continuity where d.f. $=1$ (Fisher \& Yates, 1963).

\section{Results}

\section{Experiment 1}

In the treatments where pyruvate was available during first cleavage, subsequent development to the morula stage was significantly enhanced by culture in LP medium (treatments 9, 15, 27 and 33) (Table 1). The addition of glucose to each of these treatments after the first $24 \mathrm{~h}$ of culture 
(except treatment 15) in treatments 12,30 and 36, respectively, resulted in a significant decrease in the proportion of embryos developing to the morula stage (difference between: treatments 9 and 12; 27 and $30 ; 33$ and 36, $P<0.001$ ). The reason that no significant decrease in the level of development was apparent between treatments 15 and $18(P>0.05)$ is unclear, although it appears that the presence of lactate during first cleavage may have an adverse effect on later embryonic development (compare treatments 9 and $15,41 \%$ and $33 \%$ to morula, respectively).

The presence of glucose, after the first $24 \mathrm{~h}$ of culture, therefore, had a marked inhibitory effect on the development of MF1 embryos cultured from the one-cell stage in the presence of pyruvate. This effect was not apparent when glucose was present in combination with pyruvate during the first $24 \mathrm{~h}$ of culture (difference in development to morula between treatments 9 and $27, P>0.05$ ). Cleavage to the two-cell stage, after $24 \mathrm{~h}$ of culture, was always significantly reduced in the absence of pyruvate $(P<0.001)$. Cleavage to this stage after $24 \mathrm{~h}$ in medium with pyruvate alone was significantly lower than that observed in medium with lactate and pyruvate, medium with pyruvate and glucose $(P<0.01)$ or medium with all three substrates $(P<0.001)$.

\section{Experiment 2}

Improved development of one-cell MF1 embryos to the morula stage was obtained by culture in medium with pyruvate alone, medium with lactate and pyruvate or medium with pyruvate and glucose for the first $24 \mathrm{~h}$, followed by transfer to medium containing lactate and pyruvate for subsequent culture (Table 1; treatments 9, 15 and 27, respectively). However, development of most embryos was arrested at this stage and only a few (which had been exposed to glucose during the first $24 \mathrm{~h}$ of culture; Table 1, treatment 27) developed into blastocysts. A similar 'morula stage block' to development in embryos obtained from B6CBFl hybrid mice cultured in glucosedeficient medium from the one-cell stage was overcome by the provision of glucose at or before the time of compaction on the third day post coitum (Brown \& Whittingham, 1990b, 1991). MF1 embryos cultured from the one-cell stage under these three substrate regimens were therefore transferred to complete medium containing glucose after $48 \mathrm{~h}$ of culture ( $72 \mathrm{~h}$ post hCG, four- to eightcell stage) to investigate whether this would support the morula-blastocyst transition. Since many morphologically normal but developmentally retarded morulae were observed at this time, development was also assessed after $120 \mathrm{~h}$ in culture (Table 2).

Table 2. Substrate regimens giving maximum development of one-cell MFl embryos in vitro

\begin{tabular}{|c|c|c|c|c|c|c|c|c|c|c|}
\hline \multirow{4}{*}{$\begin{array}{l}\text { Treatment } \\
\text { number }\end{array}$} & & & & \multirow{4}{*}{$\begin{array}{l}\text { Number of } \\
\text { embryos }^{b}\end{array}$} & \multicolumn{6}{|c|}{$\begin{array}{c}\text { Percentage of embryos developing to the various } \\
\text { pre-implantation stages during culture }\end{array}$} \\
\hline & \multicolumn{3}{|c|}{ Medium $^{\mathbf{a}}$} & & \multicolumn{4}{|c|}{$96 \mathrm{~h}$} & \multirow{2}{*}{\multicolumn{2}{|c|}{$120 \mathrm{~h}$}} \\
\hline & \multirow{2}{*}{$\begin{array}{c}\text { Day } \\
1\end{array}$} & \multirow{2}{*}{$\begin{array}{c}\text { Day } \\
2\end{array}$} & \multirow{2}{*}{$\begin{array}{c}\text { Days } \\
3-6\end{array}$} & & \multirow[b]{2}{*}{ Two-cell } & \multirow{2}{*}{$\begin{array}{l}\text { Four- to } \\
\text { eight-cell }\end{array}$} & \multirow[b]{2}{*}{ Morula } & \multirow[b]{2}{*}{ Blastocyst } & & \\
\hline & & & & & & & & & Morula & Blastocyst \\
\hline 1 & LPG & LPG & LPG & 80 & 100 & 83 & 18 & 9 & 20 & 15 \\
\hline 2 & LP & LP & LPG & 80 & 96 & 89 & 68 & 23 & 69 & 31 \\
\hline 3 & $\mathrm{P}$ & LP & $\mathrm{LPG}$ & 80 & 100 & 80 & 58 & 38 & 58 & 51 \\
\hline 4 & PG & LP & LPG & 80 & 99 & 95 & 80 & 39 & 81 & 56 \\
\hline
\end{tabular}

${ }^{a}$ Embryos transferred to medium on day 1, 26-27 h after hCG; day 2, 46-48 h after hCG; day 3, 70-72 h after hCG.

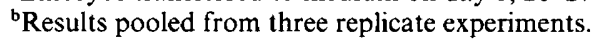

L: lactate; P: pyruvate; G: glucose.

The proportion of embryos developing to the blastocyst stage in all three experimental treatments, after $96 \mathrm{~h}$ in culture, was significantly higher than that observed in control medium with all substrates present (difference between: treatments 1 and $2(P<0.05) ; 1$ and $3 ; 1$ and $4(P<0.01)$ ). 
The proportion developing to the blastocyst stage in treatments 3 and 4 was not significantly different $(P>0.05)$, demonstrating that the presence of glucose during the first $24 \mathrm{~h}$ of culture had no detrimental effect on embryonic development. Indeed, the proportion developing to the morula stage was significantly higher in treatment 4 than in treatment $3(P<0.05)$, indicating that the presence of glucose, in combination with pyruvate, during this period has a beneficial effect on development to the morula stage.

Development to the morula stage after $96 \mathrm{~h}$ in culture in treatment 3 was not significantly higher than that in treatment $2(P>0.05)$, but the proportion developing to this stage in treatment 4 was significantly higher than that in treatment $2(P<0.05)$. This shows that, whereas the presence of lactate during first cleavage is not detrimental to embryonic development, a combination of the removal of lactate plus the addition of glucose at this time results in a significant improvement in development.

Many of the morulae observed after $96 \mathrm{~h}$ of culture had developed to the blastocyst stage $24 \mathrm{~h}$ later. The highest responses were obtained after culture in medium containing pyruvate or pyruvate plus glucose for the first $24 \mathrm{~h}$, medium containing lactate plus pyruvate for the second $24 \mathrm{~h}$, and medium containing all three substrates for the remaining culture period (treatments 3 and 4).

\section{Experiment 3}

The effect of glutamine $\left(1 \mathrm{mmol}^{-1}\right)$ on development of one-cell $\mathrm{MF} 1$ embryos in vitro was also examined (Table 3). Medium containing lactate pyruvate and glucose supported development of an unusually high proportion of one-cell MFI embryos to the blastocyst stage $(31 \%)$. Typically these embryos arrest at the two- to four-cell stage in this medium (see Tables 1 and 2); but biological variation in experimental material sometimes leads to variation in the response obtained (see Whittingham, 1975). Medium containing lactate and pyruvate supported development of $47 \%$ of embryos to the morula stage, but could not substantially support the morula-blastocyst transition $(1 \%)$. The addition of glutamine to medium containing lactate and pyruvate significantly reduced development to the morula stage $(P<0.01)$. One-cell MFl embryos failed to cleave in medium containing glutamine as the sole energy substrate, and all degenerated within the first $24 \mathrm{~h}$ of culture.

Table 3. Effect of glutamine $\left(1 \mathrm{mmol}^{-1}\right)$ on the development of one-cell MF1 embryos in vitro

\begin{tabular}{lccccc}
\hline & & \multicolumn{3}{c}{$\begin{array}{c}\text { Percentage of embryos developing to } \\
\text { the various pre-implantation stages } \\
\text { during } 96 \text { h in culture }\end{array}$} \\
\cline { 3 - 6 } Medium & $\begin{array}{c}\text { Number of } \\
\text { embryos }\end{array}$ & Two-cell & $\begin{array}{c}\text { Four- to } \\
\text { eight-cell }\end{array}$ & Morula & Blastocyst \\
\hline LPG & 130 & 86 & 72 & 45 & 31 \\
LP & 130 & 92 & 81 & 47 & 1 \\
LP glutamine & 130 & 91 & 77 & 28 & 0 \\
Glutamine & 130 & 0 & 0 & 0 & 0 \\
\hline
\end{tabular}

${ }^{a}$ Results pooled from three replicate experiments.

L: lactate; P: pyruvate; G: glucose.

\section{Discussion}

Our results showed that exogenous glucose inhibits development of one-cell embryos from random-bred MF1 mice, when present during the second $24 \mathrm{~h}$ of culture (two- to four-cell stage), 
confirming, in part, the findings of Chatot et al. (1989) obtained with embryos from random-bred CF-1 mice. They suggested that the inhibition operated throughout the first $48 \mathrm{~h}$ of culture, but did not examine the effect of glucose specifically during the first $24 \mathrm{~h}$. No inhibitory effect was observed during the first $24 \mathrm{~h}$ of culture in the present study. Indeed, when present in combination with pyruvate during this period, glucose significantly enhanced development to the morula stage.

In contrast to the findings of Chatot et al. (1989) the addition of 1 mmol glutamine $1^{-1}$ to medium containing lactate and pyruvate resulted in a significant inhibition of development. The difference between the two studies may be related to variations in the ability of CF-1 and MF1 embryos to metabolize glutamine. Strain-dependent differences in the ability of mouse embryos to metabolize particular substrates have previously been shown. For example, significantly more B6CBF1 than MF1 embryos undergo first cleavage in medium containing either lactate or glutamine as the sole energy substrate (Expt 3; Brown \& Whittingham, 1991). In addition embryos were cultured in an atmosphere of $5 \% \mathrm{CO}_{2}$ in air (Biggers et al., 1971) in the present study, but Chatot et al. (1989) used a reduced-oxygen atmosphere of $5 \% \mathrm{CO}_{2}, 5 \% \mathrm{O}_{2}$ and $90 \% \mathrm{~N}_{2}$ which is thought to favour development from the one-cell stage to blastocyst, at least in culture systems without an oil overlay (Whitten, 1971; Quinn \& Harlow, 1978), and manipulation of a single variable can significantly affect the influence of other variables (e.g. energy source and $\mathrm{pH}$; Brinster,

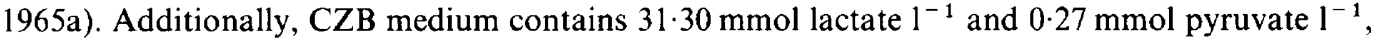
whereas $\mathrm{M} 16$ contains $23.28 \mathrm{mmol}$ lactate $1^{-1}$ and $0.33 \mathrm{mmol}$ pyruvate $1^{-1}$, and changing the type, concentration or combination of substrates significantly affects the influence of other substrates on development (Brinster, 1965b).

The mammalian embryo is exposed to a continually changing environment as it moves along the female reproductive tract, passing from a mainly pyruvate-dominated milieu to a more complex fluid environment after dispersal of the cumulus mass (Donahue \& Stern, 1968; Leese \& Barton, 1985; Gardner \& Leese, 1990). The nutrient requirements also change from a predominantly tricarboxylic acid (TCA) based, to a glycolytic-based metabolism at about the time of compaction and entry into the uterus (Brinster, 1969; Leese \& Barton, 1984; Gardner \& Leese, 1986). Gardner \& Leese (1990) have suggested that optimal development in vitro may therefore require two or more media to reflect changing conditions in vivo. These results support this suggestion, since greatest development of one-cell random-bred MF1 embryos was achieved with medium containing pyruvate (with or without glucose) for the first $24 \mathrm{~h}$, medium containing lactate and pyruvate for the second $24 \mathrm{~h}$, and medium with all three substrates thereafter.

The concentrations of the substrates were based on the levels found to be optimal for the culture of late two-cell random-bred Swiss mouse embryos by Brinster $(1965 \mathrm{a}, \mathrm{b})$. They do not necessarily reflect true in vitro optima for the different developmental stages, but the beneficial effect of a dynamic substrate regimen is clearly indicated. Further examination of the effect of varying both the combination and concentration of energy substrates at different stages of development will be necessary to produce more appropriate regimens for culturing embryos that arrest in vitro during early cleavage. The appropriateness of using high lactate concentrations $\left(20-30 \mathrm{mmol}^{-1}\right)$, as in most commonly used embryo culture media, is particularly in question, since both Wales \& Whittingham (1973) and Gardner \& Leese (1990) have obtained similar developmental responses in the presence of more physiological lactate levels $\left(4.0 \mathrm{mmol} \mathrm{l}^{-1}\right.$ and $4.79 \mathrm{mmol} \mathrm{l}^{-1}$, respectively).

The reasons why cleavage to the two-cell stage after $24 \mathrm{~h}$ of culture is enhanced by the presence of lactate or glucose, or both, in combination with pyruvate (Expt 1), yet development to the blastocyst stage is reduced if lactate is provided in combination with pyruvate at this stage (Expt 2), are unclear. However, this highlights the caution that must be taken in inferring subsequent viability on the basis of a particular experimental end-point. Caution should also be exercised in inferring that treatments that produce optimum development to the blastocyst stage in vitro will also produce optimal viability after implantation.

Lawitts \& Biggers (1991) described a radical and innovative method for designing culture media by the technique of simplex optimization (Spendley et al., 1962). They suggest that this will provide 
an efficient means of determining the requirements of mammalian embryos in vitro, especially those that arrest in vitro at various preimplantation stages, and show that optimum development can be obtained in a variety of defined media, the component concentrations of which may bear little relationship to the physiological levels found in vivo. However, the postimplantation viability of embryos grown in such media has yet to be established.

The preimplantation embryos of most mammals, including humans, have persistently proved refractory to culture in simple chemically defined media. When designing media, caution must be taken in extrapolating from results obtained in any single species, as emphasized by the recent observation of marked differences in the substrate requirements of mouse and hamster embryos (McKiernan et al., 1991). However, certain common features appear to be emerging. For example, the inhibitory effect of glucose during early cleavage, originally reported in the hamster (Schini \& Bavister, 1988), has now been observed in both random-bred mouse (Chatot et al., 1989; Aoki et al., 1990; this paper) and cattle embryos (Ellington et al., 1990), although glucose may be required to support normal development through the later morula-blastocyst transition (Brown \& Whittingham, 1991).

Seshagiri and Bavister $(1989 \mathrm{a}, \mathrm{b})$ have suggested that the inhibitory effect of glucose is due to inadequate energy generation mediated by the 'Crabtree effect' (Crabtree, 1929), whereby glucose stimulates glycolysis, which then competes with mitochondrial respiration for phosphate. However, increasing the phosphate concentration in the medium, which would be expected to overcome this effect (Koobs, 1972), fails to obviate the glucose inhibition to development, a result which they admit is not easily explained by this model. An alternative model is therefore proposed. It is well known that unicellular organisms and cultured cells transcribe specific metabolic genes in response to changes in the availability of different carbon sources. However, many of these genes cannot be expressed if glucose is also present. This phenomenon has been termed 'glucose repression' or 'catabolite repression' (Magasanik, 1961). Recently, it has been shown that transcription of the $f b p-1$ gene in Schizosaccharomyces pombe, which codes for fructose-1,6bisphosphatase, is one of the genes subject to glucose repression (Hoffman \& Winston, 1991). This may be significant, since fructose-1,6-bisphosphate synthesis is downregulated in cultured mouse embryos prior to the eight-cell stage (Barbehenn et al., 1974). It is therefore possible that 'glucose repression' in vitro during the critical period when transcription of the embryonic genome is initiated (Flach et al. 1982; Bolton et al., 1984) leads to the inhibition of normal in vivo metabolic flux, and that this is why removal of glucose from the medium results in enhanced embryonic development. Glucose repression could also explain the successful rescue of in vitro arrested embryos by the injection of cytoplasm from non-blocking embryos (Muggleton-Harris et al., 1982), as the transfer of particular enzymes, their mRNAs, or both, has been proposed as one of the potential rescue mechanisms (Muggleton-Harris \& Brown, 1988). Confirmation of this suggestion awaits further analysis at the biochemical and molecular level.

In summary, these results suggest that culture systems should reflect the dynamic changes occurring in vivo to achieve the development of viable embryos in vitro. Further work is necessary to determine which components, in what concentrations and at which stages, are required to produce viable embryos after culture.

The authors would like to thank David Gilburt for excellent technical assistance, and Cindy Welch for typing the manuscript. We would also like to thank J. A. Lawitts and J. D. Biggers for so kindly providing access to their results prior to publication. J. Brown was the recipient of an MRC Postgraduate Studentship.

\section{References}

Abramczuk, J., Solter, D. \& Koprowski, H. (1977) The beneficial effect of EDTA on development of mouse one-cell embryos in chemically defined medium. Developmental Biology 61, 378-383.
Aoki, K., Nakamura, M., Okinaga, S. \& Arai, K. (1990) The effect of glucose and phosphate on mouse twocell embryos to develop in vitro. Zoological Science 7, 973-977. 
Barbehenn, E.K., Wales, R.G. \& Lowry, O.H. (1974) The explanation for the blockade of glycolysis in early mouse embryos. Proceedings of the National Academy of Sciences USA 71, 1056-1060.

Biggers, J.D. (1971) New observations on the nutrition of the mammalian oocyte and the preimplantation embryo. In The Biology of the Blastocyst, pp. 319382. Ed. R. J. Blandau. University of Chicago Press, Chicago.

Biggers, J.D. (1987) Pioneering mammalian embryo culture. In The Mammalian Preimplantation Embryo, pp. 1-22. Ed. B. D. Bavister. Plenum Press, New York.

Biggers, J.D., Whittingham, D.G. \& Donahue, R.P. (1967) The pattern of energy metabolism in the mouse oocyte and zygote. Proceedings of the National Academy of Sciences USA 58, 560-567.

Biggers, J.D., Whitten, W.K. \& Whittingham, D.G. (1971) The culture of mouse embryos in vitro. In Methods in Mammalian Embryology, pp. 86-116. Ed. J. C. Daniel. Freeman, San Francisco.

Bolton, V.N., Oades, P.J. \& Johnson, M.H. (1984) The relationship between cleavage, DNA replication and gene expression in the mouse 2-cell embryo. Journal of Embryology and Experimental Morphology 79, 139-163.

Brinster, R.L. (1965a) Studies on the development of mouse embryos in vitro. II. The effect of energy source. Journal of Experimental Zoology 158, 59-68.

Brinster, R.L. (1965b) Studies on the development of mouse embryos in vitro. IV. Interaction of energy sources. Journal of Reproduction and Fertility 10, 227-240.

Brinster, R.L. (1969) Mammalian embryo culture. In The Mammalian Oviduct, pp. 419-444. Eds E. S. E. Hafez \& R. J. Blandau. University of Chicago Press, Chicago.

Brown, J.G. \& Whittingham, D.G. (1990a) A dynamic energy regime improves development of random bred 1-cell mouse embryos in vitro. Human Reproduction Supplement 5, 23.

Brown, J.J.G. \& Whittingham, D.G. (1990b) Glucose requirement for morula to blastocyst transition during culture of 1-cell $\mathrm{F}_{2}$ hybrid mouse embryos. Journal of Reproduction and Fertility Abstract Series $5,16$.

Brown, J.J.G. \& Whittingham, D.G. (1991) The roles of pyruvate, lactate and glucose during preimplantation development of embryos from $\mathrm{F}_{1}$ hybrid mice in vitro. Development 112, 99-105.

Carney, E.W. \& Bavister, B.D. (1987) Stimulatory and inhibitory effects of amino acids on development of hamster eight-cell embryos in vitro. Journal of In Vitro Fertilization and Embryo Transfer 4, 162-167.

Chatot, C.L., Ziomek, C.A., Bavister, B.D., Lewis, J.L. \& Torres, I. (1989) An improved culture medium supports development of random-bred 1-cell mouse embryos in vitro. Journal of Reproduction and Fertility 86, 679-688.

Chatot, C.L., Lewis, J.L., Torres, I. \& Ziomek, C.A. (1990a) Development of 1-cell embryos from different strains of mice in CZB medium. Biology of Reproduction 42, 432-440.

Chatot, C.L., Tasca, R.J. \& Ziomek, C.A. (1990b) Glutamine uptake and utilization by preimplantation mouse embryos in CZB medium. Journal of Reproduction and Fertility 89, 335-346.

Crabtree, H.G. (1929) Observations on the carbohydrate metabolism of tumours. Biochemical Journal 23, 536-545.

Cross, P.C. \& Brinster, R.L. (1973) The sensitivity of one-cell mouse embryos to pyruvate and lactate. Experimental Cell Research 77, 57-62.

Donahue, R.P. \& Stern, S. (1968) Follicular cell support of oocyte maturation: production of pyruvate in vitro. Journal of Reproduction and Fertility 17, 395-398.

Ebert, K.M. \& Brinster, R.L. (1983) Rabbit $\alpha$-globin messenger RNA translation by the mouse ovum. Journal of Embryology and Experimental Morphology 74, $159-168$.

Ellington, J.E., Carney, E.W., Farrell, P.B., Simkin, M.E. \& Foote, R.H. (1990) Bovine 1-2-cell embryo development using a simple medium in three oviduct epithelial cell coculture systems. Biology of Reproduction 43, 97-104.

Fisher, R.A. \& Yates, F. (1963) Statistical Tables for Biological, Agricultural and Medical Research. Hafner, New York.

Flach, G., Johnson, M.H., Braude, P.R., Taylor, R.A.S. \& Bolton, V.N. (1982) The transition from maternal to embryonic control of preimplantation mouse development. EMBO Journal 1, 681-686.

Fulton, B.P. \& Whittingham, D.G. (1978) Activation of mammalian oocytes by intracellular injection of calcium. Nature 273, 149-151.

Gardner, D.K. \& Leese, H.J. (1986) Noninvasive measurement of nutrient uptake by single cultured preimplantation mouse embryos. Human Reproduction 1, 25-27.

Gardner, D.K. \& Leese, H.J. (1990) Concentrations of nutrients in mouse oviduct fluid and their effects on embryo development and metabolism in vitro. Journal of Reproduction and Fertility 88, 361-368.

Hoffman, C.S. \& Winston, F. (1991) Glucose repression of transcription of the Schizosaccharomyces pombe $f b p-I$ gene occurs by a cAMP signaling pathway. Genes and Development 5, 561-571.

Koobs, D.H. (1972) Phosphate mediation of the Crabtree and Pasteur effects. Science 178, 127-133.

Lawitts, J.A. \& Biggers, J.D. (1991) Optimization of mouse embryo culture media using simplex methods. Journal of Reproduction and Fertility 91, 543-556.

Leese, H.J. \& Barton, A.M. (1984) Pyruvate and glucose uptake by mouse ova and preimplantation embryos. Journal of Reproduction and Fertility 72, 9-13.

Leese, H.J. \& Barton, A.M. (1985) Production of pyruvate by isolated mouse cumulus cells. Journal of Experimental Zoology 234, 231-236.

McKiernan, S.H., Bavister, B.D. \& Tasca, R.J. (1991) Energy substrate requirements for in vitro development of hamster 1 - and 2-cell embryos to the blastocyst stage. Human Reproduction 6, 64-75.

Magasanik, B. (1961) Catabolite repression. Cold Spring Harbor Symposium Quantitative Biology 26, 249-256.

Muggleton-Harris, A.L. \& Brown, J.J.G. (1988) Cytoplasmic factors influence mitochondrial reorganization and resumption of cleavage during culture of 
early mouse embryos. Human Reproduction 3, 1020-1028.

Muggleton-Harris, A., Whittingham, D.G. \& Wilson, L. (1982) Cytoplasmic control of preimplantation development in vitro in the mouse. Nature 299, 460-462.

Quinn, P. \& Harlow, G.M. (1978) The effect of oxygen on the development of preimplantation embryos in vitro. Journal of Experimental Zoology 206, 73-80.

Quinn, P., Barros, C. \& Whittingham, D.G. (1982) Preservation of hamster oocytes to assay the fertilizing capacity of human spermatozoa. Journal of Reproduction and Fertility 66, 161-168.

Schini, S.A. \& Bavister, B.D. (1988) Two-cell block to development of cultured hamster embryos is caused by phosphate and glucose. Biology of Reproduction 39, 1183-1192.

Seshagiri, P.B. \& Bavister, B.D. (1989a) Glucose inhibits development of hamster 8-cell embryos in vitro. Biology of Reproduction 40, 599-606.

Sheshagiri, P.B. \& Bavister, B.D. (1989b) Phosphate is required for inhibition by glucose of development of hamster 8-cell embryos in vitro. Biology of Reproduction 40, 607-614.

Spendley, W., Hext, G.R. \& Himsworth, F.R. (1962) Sequential application of simplex designs in opti- misation and evolutionary operation. Technometrics 4, 441-461.

Wales, R.G. \& Whittingham, D.G. (1973) The metabolism of specifically labelled lactate and pyruvate by two-cell mouse embryos. Journal of Reproduction and Fertility 33, 207-222.

Whitten, W.K. (1971) Nutrient requirements for the culture of preimplantation embryos in vitro. In Advances in the Biosciences, Vol. 6, pp. 129-140. Ed. G. Raspa. Pergamon Press, Oxford.

Whitten, W.K. \& Biggers, J.D. (1968) Complete development in vitro of the preimplantation stages of the mouse in a simple chemically defined medium. Journal of Reproduction and Fertility 17, 399-401.

Whittingham, D.G. (1971) Culture of mouse ova. Journal of Reproduction and Fertility Supplement 14, 7-21.

Whittingham, D.G. (1975) Fertilisation, early development and storage of mammalian ova in vitro. In The Early Development of Mammals, pp. 1-24. Eds M. Balls \& A. Wild. Cambridge University Press, Cambridge.

Whittingham, D.G. \& Biggers, J.D. (1967) Fallopian tube and early cleavage in the mouse. Nature 213, 942-943.

Received 3 April 1991 